\title{
Natural Gas Pricing in Eastern Europe
}

\author{
Valentyna Novosad \\ Scientific company "MAE", Horyva st, Kyiv, Ukraine
}

Email address:

mae2010@meta.ua

\section{To cite this article:}

Valentyna Novosad. Natural Gas Pricing in Eastern Europe. Journal of Energy and Natural Resources. Special Issue: Marketing in Energy Pricing. Vol. 5, No. 3-1, 2016, pp. 9-12. doi: 10.11648/j.jenr.s.2016050301.13

\begin{abstract}
Energy pricing, especially natural gas pricing is very important for all organizations and households. In many cases natural gas pricing has a significant effect on the formation of tariffs for electricity and the prices for heating and hot water. The formation of natural gas prices in Eastern Europe has its destructive features. This is due to shortage of domestic production and supplies of natural gas from Russia. In this article we examined these features and tried to give recommendations how to use these features to support own economics and prevent a fall of living standards of people in these countries.
\end{abstract}

Keywords: Economy, Marketing, Natural Gas Pricing, Natural Gas Market

\section{Introduction}

Energy pricing has a significant impact on activity of all organizations. Each household budget is greatly affected by the cost of energy. Therefore consideration of energy pricing is so important and relevant. [3].

Because the prices for natural gas have an independent value to the budgets of industry and households as well as a significant impact on the price formation for electricity and heating, the issue of the natural gas pricing is especially important for the every country.

At the same time in Europe natural gas prices are heavily dependent on external supplies of natural gas, particularly from Russia. Gazprom supplied Europe with 161, 5 billion cubic meters of natural gas in 2013. Today Gazprom remains the key gas supplier to the Europe. [6].

\section{Main Part}

In recent years the prices of natural gas have substantially decreased, but in comparison with the United States [tab.1] and Russian prices, [tab.2]European natural gas prices are still high [tab.3].

Table 1. Export-import prices of natural gas in US*

\begin{tabular}{lllll}
\hline & Nov.2014 & \multicolumn{3}{c}{ Apr.2015 } \\
\hline & $\$ / \mathrm{fit3}$ & $\$ / \mathrm{m} 3$ & $\$ / \mathrm{ft} 3$ & $\$ / \mathrm{m} 3$ \\
Import price & 3,97 & 140 & 2,59 & 92 \\
Export price & 4,44 & 157 & 2,88 & 102 \\
\hline
\end{tabular}

*A source of information $[7,8,10]$
Table 2. Wholesale price in Russia*.

\begin{tabular}{lll}
\hline & Rub/1000m3 & \$/1000m3 \\
\hline Moscow Region with tax,2015 & 3761 & 68 \\
\hline
\end{tabular}

${ }^{*}$ A source of information $[6,8,9,11]$

The dollar exchange rate as of June2015

Table 3. Prices for natural gas to Europe (average)*.

\begin{tabular}{lll}
\hline Years & \$/MMbtu & $\mathbf{\$ 1 0 0 0 m 3}$ \\
\hline 2011 & 10,3 & 390 \\
2012 & 11,69 & 443 \\
2013 & 12,29 & 465 \\
2014 & 10,2 & 387 \\
2015 & 7,27 & 276 \\
\hline
\end{tabular}

${ }^{*}$ A source of information $[5,8,10,11]$

High natural gas prices have a negative impact on the competitiveness of goods and welfare of European countries. If European countries with-developed economy can withstand this high level of the imported natural gas prices, in Eastern European Countries such prices may destroy their economy.

If we consider the prices of natural gas of the each country for end users, all European countries can be divided into 4 four groups.

1. Natural gas prices in the developed European countries.

2. Natural gas prices in the Eastern European Countries, which are part of the European Union (EU).

3. Natural gas prices in the Eastern European Countries, which are not part EU.

4. Natural gas prices in the Russia. 
Table 4. Natural gas prices in well developed European countries*.

\begin{tabular}{|c|c|c|c|c|c|}
\hline \multirow[b]{2}{*}{ Countries } & \multicolumn{2}{|c|}{ Industry } & \multicolumn{2}{|c|}{ Household } & \multirow{2}{*}{$\begin{array}{l}\text { \% } \\
\text { Household to } \\
\text { Industry }\end{array}$} \\
\hline & $\begin{array}{l}\text { Euro/ } \\
\text { kWh }\end{array}$ & $\begin{array}{l}\$ / \\
1000 \mathrm{~m} 3\end{array}$ & $\begin{array}{l}\text { Euro/ } \\
\text { kWh }\end{array}$ & $\begin{array}{l}\$ / \\
1000 \mathrm{~m} 3\end{array}$ & \\
\hline EU28 & 0,0373 & 392 & 0,0544 & 572 & 146 \\
\hline UK & 0,0344 & 362 & 0,0560 & 589 & 162 \\
\hline Germany & 0,438 & 460 & 0,519 & 546 & 119 \\
\hline France & 0,0376 & 395 & 0,0606 & 657 & 162 \\
\hline Italy & 0.0352 & 370 & 0,0621 & 658 & 178 \\
\hline Spain & 0,0371 & 390 & 0,0714 & 751 & 193 \\
\hline
\end{tabular}

*A source of information $[1,2,8,10,11]$

The dollar exchange rate as of June2015

Table 5. Natural gas prices in the Eastern European Countries, which are part of the European Union $(E U)^{*}$.

\begin{tabular}{lllllll}
\hline \multirow{2}{*}{ Countries } & \multicolumn{3}{l}{ Industry } & \multicolumn{2}{l}{ Household } & \% \\
\cline { 2 - 5 } & $\begin{array}{l}\text { Euro/ } \\
\text { kWh }\end{array}$ & $\begin{array}{l}\text { \$ } / \\
\mathbf{1 0 0 0 m 3}\end{array}$ & $\begin{array}{l}\text { Euro/ } \\
\text { kWh }\end{array}$ & $\begin{array}{l}\text { \$ } / \\
\mathbf{1 0 0 0 m 3}\end{array}$ & $\begin{array}{l}\text { Household } \\
\text { to Industry }\end{array}$ \\
\hline Czech & 0,0320 & 307 & 0,0475 & 500 & 148 \\
Republic & 0,0335 & 352 & 0,0374 & 393 & 112 \\
Estonia & 0,036 & 382 & 0,0414 & 436 & 114 \\
Poland & 0,0363 & 218 & 0,0161 & 169 & 78 \\
Romania & 0,0207 & 218 & \\
Greece & 0,0438 & 461 & 0,0728 & 766 & 165 \\
\hline
\end{tabular}

*A source of information $[1,2,8,10,11]$

The dollar exchange rate as of June2015

Table 6. Natural gas prices in the Eastern European Countries, which are not part $E U^{*}$

\begin{tabular}{|c|c|c|c|c|c|}
\hline \multirow[b]{2}{*}{ Countries } & \multicolumn{2}{|c|}{ Industry } & \multicolumn{2}{|c|}{ Household } & \multirow{2}{*}{$\begin{array}{l}\% \\
\text { Household } \\
\text { to Industry }\end{array}$} \\
\hline & $\begin{array}{l}\mathrm{NV} / \\
1000 \mathrm{~m} 3\end{array}$ & $\begin{array}{l}\text { \$/ } \\
1000 \mathrm{~m} 3\end{array}$ & $\begin{array}{l}\text { NV/ } \\
1000 \mathrm{~m} 3\end{array}$ & $\begin{array}{l}\$ / \\
1000 \mathrm{~m} 3\end{array}$ & \\
\hline $\begin{array}{l}\text { Belarus, } \\
\text { NV=BYR }\end{array}$ & - & 276 & 2588000 & 168 & 61 \\
\hline $\begin{array}{l}\text { Ukraine, } \\
\text { NV= UAN }\end{array}$ & 8975 & 427 & 7188 & 342 & 80 \\
\hline $\begin{array}{l}\text { Moldova, } \\
\text { NV=MDL }\end{array}$ & 6301 & 333 & 6718 & 355 & 108 \\
\hline
\end{tabular}

*A source of information $[12,14,15,16,18,20]$

The dollar exchange rate as of June2015

Table 7. Natural gas prices in the Russia*

\begin{tabular}{|c|c|c|c|c|c|}
\hline \multirow[b]{2}{*}{ Country } & \multicolumn{2}{|c|}{ Industry } & \multicolumn{2}{|c|}{ Household } & \multirow{2}{*}{$\begin{array}{l}\% \\
\text { Household to } \\
\text { Industry }\end{array}$} \\
\hline & $\begin{array}{l}\text { RUB/ } \\
1000 \mathrm{~m} 3\end{array}$ & $\begin{array}{l}\$ / \\
1000 \mathrm{~m} 3\end{array}$ & $\begin{array}{l}\text { RUB/ } \\
1000 \mathrm{m3}\end{array}$ & $\begin{array}{l}\$ / \\
1000 \mathrm{~m} 3\end{array}$ & \\
\hline Russia & 4043 & 73 & 4334 & 78 & 107 \\
\hline
\end{tabular}

*A source of information $[13,9]$

The dollar exchange rate as of June2015

The tables of natural gas prices for end users in Europe reflect the policy of different countries in the pricing and effects of this policy.

Simple copying by Greece of high European prices and high correlation between prices for industry and households has not led to the best result. More reasonable prices and the ratio between the prices for industry and households in other European countries allow to gradually raise the country's economy and improve the society welfare.

Countries that don't hurry to set high energy prices, especially for natural gas, taking into account own participation in the Eastern markets, including Russian, make its industry as competitive and provide opportunities for the people to develop their households and to quickly reach the European standards of living.

The main characteristics of Eastern European Countries are Geographical location, historical development through the stage of socialism and the social consequences of this in the form of lower living standards for the population On the one hand they have a European markets with high prices and high quality products. On the other hand they have markets of Russia and other countries, which could have demand to their goods, but with a lower price than goods of highly developed countries.

Thus, economy of these countries depends not only on prices of imported energy resources, but also on the cost of energy resources in Russia and other countries. At the same time, these countries should have lower prices for imported natural gas from Russia considering lower transport costs.

These features can be an advantage for the development of their economy or an obstacles for it Blind adherence to the rules and prices of developed European countries can lead to a drop in the economy and impoverishment of their people faster than the approximation to the level of economy and life of the developed countries.

Before establishment of prices for the widely used in all spheres of countries life natural gas, its necessary to conduct the marketing research of all consumers to encourage them to economical use it, but don't harm them. The use of the principles of marketing in these cases is most effective means of helping to regulate the relationships between supplies and consumers.

In all countries there are two main categories of natural gas consumers. This is industry and households. We will consider these indicative categories of natural gas consumers in Eastern European countries.

\subsection{Industry}

Many years have passed since "era" of socialism, therefore industry of these countries has a very diverse structure. Some companies received investment and using the cheap labor, produce high-quality products and sell it with a good profit in Western countries. They are able to pay the cost of energy at a price corresponding to the European level of price.

Companies that sell their products to Russia and other countries with lower energy prices could lose its share on these commodity markets, if the prices of energy resources will be much higher than for products of other countries. When setting prices for natural gas for industrial enterprises, it is necessary to take into account these features in order to avoid the collapse of some businesses and increase unemployment in this regard. Therefore it is necessary to more carefully consider of all consumers in each category and to divide them into smaller groups.

\subsection{Householders}

Householders are another very important category of 
natural gas consumers. This category of consumers has also within a variety of structure. Some consumer groups in this category are too sensitive to an increase in natural gas prices. High average European prices for natural gas and the cost of municipal services to the consumers don't stimulate to the savings of energy resources because households in any case will not be able to pay the bills. At the same time in all Eastern European Countries there are consumers who not only can afford to pay for the consumed natural gas, but also can increase their consumption even at the highest price. As well as with an increase of natural gas prices, the interests of those consumers, who use this energy resource just for cooking, will be affected less than the interests of consumers who use natural gas also for heating and for the preparing of hot water. At the same time the owners of the private houses where natural gas is used for heating and hot water are also very different in terms of consumption and in their capacity to pay bills.

There may be:

- Retirees, who consume a small amount of natural gas, but this amount exceeds their ability to pay;

- Large families in houses with area $300-500 \mathrm{~m} 2$ with one breadwinner;

- Businessmen of the average level, who can regulate their consumption using the methods of energy conservation;

- Owners of huge property who are more concerned of better security of supply and technical services for gas supply system of their huge households than in lower prices.

All these supply conditions, technical requirements and the ability to pay bills, you can find using the methods of marketing research. Currently in Eastern European countries subsidies are only provided to the poorest members of society as well as in some countries there are different prices for different amounts of natural gas consumed by one household.

\subsection{Regulation of Relationships}

Marketing research of all consumers enables to have them countries not only debate whether"to raise or not raise" the prices of energy resources, but to regulate all relationships of customers and suppliers so that the interests of all participants of the process of the supply and consumption of natural gas are taken into account This means the authorities which engaged in the regulating the natural gas prices should be very attentive to the process of pricing natural gas and to balance the formula of equality interests (Ta) (1):

$$
\mathrm{Ta}=\frac{\mathrm{Cw} .}{\mathrm{Gc} .}=\frac{\mathrm{T} 1 * \mathrm{G} 1+\ldots+\mathrm{Ti} i \mathrm{Ci}}{\mathrm{GcTa} a=\frac{C w}{G c}=\frac{T 1 * G 1+\cdots+T i * G i}{G c}}
$$

Where,

$\mathrm{Cw}$ - all money due to the suppliers;

Gc-all consumed natural gas;

Ti-a tariff for i-consumer;

Gi- consumed natural gas by i-consumer.
In this formula the optimal tariff of the supplier is equal to the weighted average tariff of all consumers. At the same time the tariff for a particular group of consumers would correspond to an opportunity to pay bills these groups of consumers.

Work of marketing specialists together with the specialists of the industry is necessary to regulate the relationships between suppliers and natural gas consumers so that the country's economics is successfully developed, the population is not impoverished and gas industry is reliable and secure.

\section{Conclusions}

High dependence on expensive imported natural gas of European countries has a negative impact on the competitiveness of goods and welfare of the people of these countries. At the same time Eastern European countries have some features that can help them if these features are used wisely.

One feature of Eastern European countries is their geographical location. These countries are located closer to the main supplier of natural gas in Europe -to Russia. Such location gives them lower prices for imported natural gas given lower transport costs.

However Eastern European countries have the second feature. It is a lower people's salary and as result a lower life level than in developed Western European countries.

Therefore the high levels of natural gas prices have very negative impact on welfare of Eastern European countries population.

At the same time the opportunities to pay the bills of industrial enterprises and home holders are very different.

Because Eastern European countries have such features the regulation of relationships between the natural gas suppliers and natural gas consumers should be especially attentive. Using of the marketing research in the process of natural gas pricing in these countries will allow identifying small groups of the natural gas consumers with the same conditions of supplies and opportunities to pay the bills. This also is the good way to find "gold points» of the pricing system and means to regulate in the best way all relationships in the sphere the natural gas supply and consumption.

\section{References}

[1] Table14: Natural gas prices for industrial consumers. Euro stat (nrq_pc_203).

[2] Table14: Natural gas prices for household consumers. Euro stat (nrq_pc_202).

[3] Electricity and natural gas price statistics www.ec.europa.eu

[4] Europe's Energy Portal www.energy.eu

[5] European Union Natural Gas import price www.ycharts.com

[6] Gazprom Www.gazprom.com 
[7] International Energy Agency http://www.iea.org/

[8] Www.tetran.ru

[9] Www.cbr.ru

[10] Www.dolgikg.com

[11] Swiss. Executive MBA www.freecurrencyrates.com

[12] Www.ch104.ua/for.clients/do-uvagi-klijentiv

[13] Www.newtariffs.ru/2015
[14] Www.bs-life.ru/nancy/nalogy/nds.html

[15] Www.nerc.gov.ua

[16] Www.mingas.bu/services

[17] Www.Eurobelarus/news/economy/2015

[18] Www.calk.ru/kurs BYR-USD.html

[19] Www.anre.nad. 